\title{
Art, Nature, and Culinary as Leverage of Village Branding at the Foot of the Mountain
}

\author{
Soerjo Wido Minarto a,1, Rully Aprilia Zandra ${ }^{\mathrm{b}, 2,}$, , Adzrool Idzwan Ismail ${ }^{\mathrm{b}, 3}$ \\ ${ }^{a}$ Prodi Pendidikan Seni Tari dan Musik, Jurusan Seni dan Desain, Fakultas Sastra, Universitas Negeri Malang, Jl. Semarang no 5, 65113 Indonesia \\ ${ }^{\mathrm{b}}$ Scool of Creative Industry Management and Performing Art, College of Art and Science, Universiti Utara Malaysia, Sintok Kedah Darul Aman, Malaysia \\ ${ }^{1}$ soerjo.wido.fs@um.ac.id ${ }^{2}$ rullyzandra.fs@um.ac.id ${ }^{3}$ adzrool@uum.edu.my \\ * Corresponding Author
}

Received; 2021-04-23

accepted; 2021-05-09

published; 2021-11-26

\begin{abstract}
Beach tourism and seaside settlements are perennially popular. Nature's potential as well as the coast's characteristic hybrid art may always entice visitors. The settlements at the foot of the mountain, on the other hand, have their own unique environmental, gastronomic, and cultural identities. Bedugul village (Indonesia), Albarracin village (Spain), Reine village (Norway), Wengen village (Switzerland), Panglipuran village (Indonesia), Hallstatt village (Austria), Patiangan village (Indonesia), and Ora village (Indonesia) are some of the names given to the villages in Indonesia (Greece). They're all mountain communities that have successfully marketed themselves as tourist destinations at the foot of the mountain. The goal of this research is to come up with a viable approach for village branding at the foot of the mountain. This study is a hybrid of action research and development research, with a focus on tourism village acceleration. The Benjor village residents, Benjor village administrators, and a sample of potential visitors were polled for information. The community around Benjor village, the Malang Regency community, and persons outside the Malang Regency were all surveyed for potential visitors. Individual interviews or focus groups, environmental observations, and archives of village office records and Malang Regency government documents were used to gather data. The purpose of this study is to understand the tourism village process before and after therapy. Mining potential excavation yields eleven environmental assets in the form of waterfalls, five culinary assets in the form of chilli sauce, grilled rice, and other similar dishes, and three cultural assets in the form of hadrah, jaranan, and dancing. The development research yielded seven goods that Benjor villagers found to be the most effective in terms of branding. For mountain slope communities, the greatest method is to combine branded items that showcase their artistic, natural, and gastronomic potential.
\end{abstract}

\section{Introduction}

Beach tourism and coastal villages have always been an attraction (Chakraborty, Saha, and Selim 2020). Both the natural potential and the hybrid arts typical of the coast can always attract people to come (Sajnani, Mayor, and Tillberg-Webb 2020). On the other hand, the villages at the foot of the mountain also have their own environmental, culinary and artistic identity (N. Wang et al. 2021). Call it Bedugul village (Indonesia), Albarracin village (Spain), Reine village (Norway), Wengen village (Switzerland), Panglipuran village (Indonesia), Hallstatt village (Austria), Patiangan village (Indonesia), and Ora village (Greece) (Ma'arif, Syakdiah, and Anggraini 2019; Utama and Junaedi 2017). All of them are mountain villages that have succeeded in branding themselves as tourist villages at the foot of the mountain (Khairabadi, Sajadzadeh, and Mohammadianmansoor 2020). Branding is an image so that a product can attract and stick in the minds of consumers (Casidy, Wymer, and O'Cass 2018). One of the communication efforts of a regional entrepreneur is also through branding (Kong, Witmaier, and Ko 2021). The primary purpose is to introduce an image that contains mass interest towards a company or a particular location (Madleňáková, Turská, and Madleňák 2019). The location can be a province, city, or village. Branding a village has several purposes. Some aim to attract investors to invest, and some aim to attract tourists and buyers of local products (Aryanti 2015). Villages that brand themselves to stimulate mass interest in visiting tourists and buying their local products are branding for tourist villages (Zhou et al., 2021). 
A tourist village is a community space consisting of residents in a limited area (Park and Kovacs 2020). Tourist villages generally try to integrate attractions, accommodation, culinary, natural beauty, and distinctive products as a village distinction (Kastenholz, Eusébio, and Carneiro 2018). It is the distinction as the village's uniqueness that becomes the leverage on the interest of the masses to visit or repeat visits to a tourist village (Miclon et al., 2021). In addition to Bali's level I local government, the level II local government of Malang is one of the governments that is full of tourist villages as one of the national and international tourist destinations. Tourism villages in Malang Regency continue to grow dynamically. In addition to the level II Malang local government, the academic community also plays a significant role in the birth of a new tourist village. The community prepares Benjor Village as a tourist village. Benjor Village is located in Tumpang District, Malang Regency. This village is bordered by Tumpang (west), Ngadirego Village (north), Duwet Village (south) and the Tengger mountain forest in the east. The work of the majority of the people of Benjor Village is in agriculture, services, industry and several other sectors. The people of Benjor Village have advantages in various sectors. These sectors include the food sector, the nature sector, and the environmental sector (grilled chilli sauce, grilled rice, Benjor coffee, 11 waterfalls, durian, coffee, cassava, oranges, the famous three sugar cane, Coban Sanusi). However, it is unfortunate that the publications from this village are still not optimal (Jiang et al., 2021). Even though in this era of the industrial revolution 4.0, it is straightforward to publish a product or "broadcast yourself" (Burgess 2015). Many platforms can be used, such as social media, websites. The community and village officials declared Benjor a tourist village. The criteria for a good brand include being well protected, easy to pronounce, easy to remember, easy to recognize, attractive, showing product benefits, highlighting product differences compared to competitors (Porter 1989).

Research on the acceleration of tourism villages ideally raises the advantages of Benjor Village as preparation for Tourism Villages. The broader community can know them by creating "multimedia branding" in the socio-cultural and tourism sectors (Padurean 2007). Multimedia branding, in this case, will be in the form of visual, sound and motion images (Mayer and Moreno 2002). "A brand is name, term, sign, symbol, or design, or a combination of them, intended to identify the goods or service of one seller or group of sellers and to differentiate them from those of competitors." A brand is a name, term, sign, symbol, or design or a combination of them which is intended to identify the goods or services of a person or group of sellers to differentiate them from those of competitors (Tasci and Kozak 2006). Benjor Village has a lot of potentials, including culinary potential, environmental potential, and artistic potential. Culinary potential, environmental potential, and artistic potential are the capital to build village branding. These three groups of capital must be by the direction of the concept of foot-mountain tourism. Ideally, Benjor Village has logos, songs, dances, taglines, bumper videos, websites, and social media accounts to be published independently through publications from the Malang district government (Azizah et al. 2020). Making logos, songs, dances, taglines, videos, websites and social media accounts is a must in today's modern era. The research contribute Benjor village branding for creating allure and finding effective strategies for village branding at the foot of the mountain.

\section{Method}

This research is a combination of action research and development research with a tourism village acceleration perspective. This research begins with meaning the tourism village process before treatment and after the action is applied. The researcher acts as a party who feels a problem that needs to be resolved, namely the awareness of tourism assets by the village community and the lack of tourism products in Benjor Village. The scene of this research is Benjor Village in Malang Regency. Data were collected from the Benjor village community, Benjor village officials, and a sample of potential tourists. Samples of prospective tourists were taken from the community around Benjor village, the Malang Regency community, and people outside Malang Regency. Data were collected utilizing individual interviews or FGDs, environmental observations, and archives of village office documents and Malang Regency government documents. The data were analyzed based on the taxonomy of environmental, artistic, and culinary assets. Valid data are then used for citizen training and production of promotional products. The training activity is still part of the implementation of action research procedures evaluated in three cycles. Meanwhile, the production of promotional products was followed up with ten research and development procedures. 
The product was compiled to be validated by a team of validators. The validator team consists of visual, auditory, and material validators. After the initial validation, the product was tested twice. The first trial was conducted on a small group of user operators. Their criticism and input are used to improve product II. Product II was tested again on many user operators, namely all residents who have cellphones and village apparatus. All inputs from large group trials were used to build product III as the final revision and re-validated by the validator team. The final validated product is then uploaded to the website and Instagram. At the end of the development phase, the research team fully handed over the operation of the website and Instagram into the hands of residents and village officials. This submission aims to measure the final achievement of action research. The response of potential tourists is measured when residents and village officials entirely operate the website and Instagram. The responses of the three sample groups of prospective tourists were measured twice with a Likert scale questionnaire. Prospective tourists fill out questionnaires before action research and post-action research for which products have been developed.

\section{Results and Discussion}

The research team at the State University of Malang carried out this research activity to support the preparation of Benjor Village to become a tourist village. In six months, the process of exploring the potential of Benjor Village found three potentials. The three potential villages include environmental potential, artistic potential, and culinary potential. The environmental potentials of Benjor Village include Coban Cinde and Coban Sanusi. Potential arts in Benjor Village are hadrah, pencak silat, and bantengan that can lift the branding of Benjor Village. The culinary potential of Benjor Village has special foods, namely grilled rice, grilled chilli sauce, and similar crackers. It then became the basis for Benjor Village branding in promotional products in the form of audio, visual, language, logo, and social media. Based on the data on the three potentials of Benjor Village, the village's superiority is formulated in the environmental, arts, and culinary categories. Furthermore, the meetings attended by the community, village officials, and the companion team for four months resulted in two types of activities.

The activities for the first three months took the form of discussions and training. The training materials delivered during that period included: (1) tourism asset education, (2) discussions about past tourism assets, (3) discussions about the responses of people outside the village about objects in Benjor Village. In the same three months, residents and village officials trained to operate Instagram and websites on different days and produce simple promotional tools. From July 1 to August 7, 2020, the training material turned into product trials that the research team has developed. Promotional products developed are compiled referring to the results of early-stage action research. During that period, the training material was delivered in the form of a trial of promotional product I, which was operated by residents accompanied by a research team. At the same time, the research team collected user responses and samples of potential tourists to visual, sound, and slogan products. This response became a reference for the research team to revise product I into product II, which contains (1) visual (logo and dance), (2) sound (theme song and dance accompaniment), (3) language (tagline), and (4) audiovisual (video bumper), (5) social media (Instagram feed), and (6) digital address (Benjor Village website). Product II was tested on all citizens who have smartphones resulting in several evaluations based on functional conflicts, input from Instagram followers, difficulty operating the website, lack of legibility of the logo, and level of user enthusiasm.

The five inputs became the basis for the development team to revise product II into product III by simplifying features and improving the product into seven parts. Product III consists of (1) logo, (2) song, (3) dance, (4) tagline, (5) video bumper, (6) Instagram, and (7) website. The steps for the production of promotional products that were carried out before the provision of maintenance materials for the village Instagram and website included six steps, namely 1) coordinating to get the right location and time for taking photos and videos, 2) composing and recording village soundtrack songs at once dance accompaniment, 3) compose choreography and train dancers, 4) organize photos, videos, music, and songs in a comprehensive and ready-to-upload audiovisual clip, 5) invite and involve Benjor Village officials to accompany and coordinate the activities of villagers, and 7) together with residents, upload logos, photos, bumper videos, captions to Instagram and websites. Through Instagram and its website, now Benjor residents, people outside Benjor village, and even people outside Malang Regency can receive information about the tourist charm of Benjor village. As 
a potential tourist village, Benjor currently has the identity of its actual promotional product, which consists of (1) logo, (2) song, (3) dance, (4) tagline, (5) video bumper, (6) Instagram, and (7) websites. The first visual identity is the Benjor village branding logo. The logo can be seen in Figure 1.

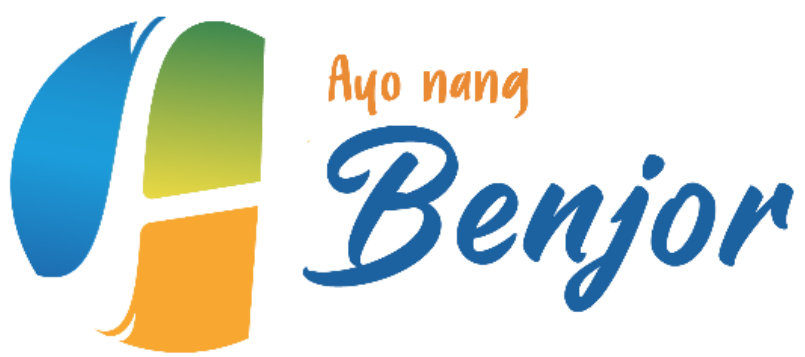

Fig. 1. Logo branding Benjor villages

Of course, every visual identity of the logo must have a meaning (Bonnardel et al. 2020), as well as in designing the Benjor Village logo as a Tourism Village, which has or depicts three village icons in the form of Coban, Bamboo and Water. On the left side, the blue one represents the colour of the water, which has the meaning of sesanti desa, namely "omben-omben sak lonjor". On the right side is a yellow bamboo with green gradations, representing local plants represent commonly found in Benjor Village. On the middle side, it has white space, which represents the waterfall's shape as one of the leading destinations and is widely visited. This symbolic visual depiction is also trying to be represented in an auditive form in the song Kibar Benjor and dance moves entitled Ayo Nang Benjor. The song Kibar Benjor is lyrical music composed in a blend of Western-style cantus firmus centric composition techniques hybridized with Javanese gamelan pentatonic (Yampolsky 2018). This kind of music is arranged so that it is easy for tourists to digest popular sounds but still does not leave the Javanese identity as the locus that is being promoted. The musical style and modality of local wisdom need to be stated as the identity of the locus (Marshall and Naumann 2018). Table 1 is the lyrics of the song Kibar Benjor.

Table 1. Lyrics of Song titled Kibar Benjor by. Rully Aprilia Zandra

\begin{tabular}{cc}
\hline Song Text & meaning \\
\hline Yo ayo yo ayo yo ayo & Yo come on yo come on yo come on \\
Yo ayo yo ayo yo ayo & Yo come on yo come on yo come on \\
Yo ayo yo ayo yo ayo & Yo come on yo come on yo come on \\
Ayooo nang benjor & Yo come on yo come on yo come on \\
Desa Benjor desa ing Gunung Bromo & Come on to Benjor \\
Desa tentrem sing wates kalih alas & Benjor village is a village on Mount Bromo \\
Penduduk e grapyak sehat lan makmur & A peaceful village that makes wates kalih \\
Bertani kopi kegiatanipun & The people are friendly, healthy and prosperous \\
Kopi Benjor kopine masyarakat & Coffee farming activities \\
Coban Cinde iku tujuan pariwisata & Benjor coffee is the community's coffee \\
Mlampah-mlampah sesarengan sederek & Coban Cinde is a tourism destination \\
Numpak Jeep sesarengan marai ati bungah & take a walk with the brothers \\
Jaya dan majulah berkibar selalu Desa Benjor & Jaya and go forth always be the village of Benjor \\
Bangkit, tegakkan semangat Desa Benjorku & Rise up, uphold the spirit of Benjorku Village \\
\hline
\end{tabular}

The lyrics of the Kibar Benjor song above describe the beautiful atmosphere of Benjor Village. Located at the foot of Mount Bromo, it has friendly people who like to grow coffee. Kibar Benjor also depicts a portrait of an exciting tourist destination to visit. Kibar Benjor's song has been published and obtained a copyright certificate with the number 000202276. Besides being the official village song, the Kibar Benjor song is also used as dance accompaniment music. The dance accompanied by the song Kibar Benjor is the Ayo Nang Benjor dance. The Ayo Nang Benjor dance depicts the people of Benjor village who work hard, are friendly, light-hearted, and get along well. The Ayo Nang Benjor dance is danced by four people wearing pink costumes and hats that are often used by the people of Benjor Village in farming. The Ayo Nang Benjor dance movements depict people picking coffee, making grilled chilli sauce, cooking grilled rice, and processing bamboo into skewers. Movements 
that are simple but easy to understand are deliberately structured to make them accessible for tourists to interpret (L. Wang and Kirilenko 2021). Confirmation of interpretation also appears in the lyrics of the song Kibar Benjor with the slogan being sung repeatedly, saying the phrase "Ayo Nang Benjor".

The tagline "Come on nang Benjor" has a persuasive meaning to invite the public to visit Benjor Village. Using the local accent of Malang, it is hoped that this tagline can have more identity (Kladou et al., 2017). If the tagline is associated with the logo, it will appear synchronization between the two. The colour of the logo uses a gradation of 4 solid colours, namely Orange, Yellow, Green and Blue. Orange colour gives a warm and vibrant impression, and Orange also symbolizes optimism, selfconfidence and intense socialization. Yellow colour means joy or intelligence. Blue colour means comfortable, calm, peaceful, relaxed and communicative. The colour green has the meaning of fertility, success and growth. All of them have been considered as carefully as possible based on the scientific background (Lichtenfeld et al., 2012). The bumper video from Benjor Village shows the natural potential, culinary potential, and community activities in Benjor Village (Satria 2009; Damiasih and Isdarmanto 2020). There are 11 natural potentials shown in the bumper video, and there are three famous trials, namely the Cinde Coban, the Sanusi Coban, and the Manten Coban. The culinary potential highlighted in the bumper video of Benjor Village is about Benjor speciality coffee, durian fruit, jackfruit, and cassava plants. In addition, the bumper video has also featured community activities growing coffee and making skewers. Bumper videos from Benjor Village can be accessed through social media, Instagram, and the website. Figure 2 is the Instagram of Benjor village.

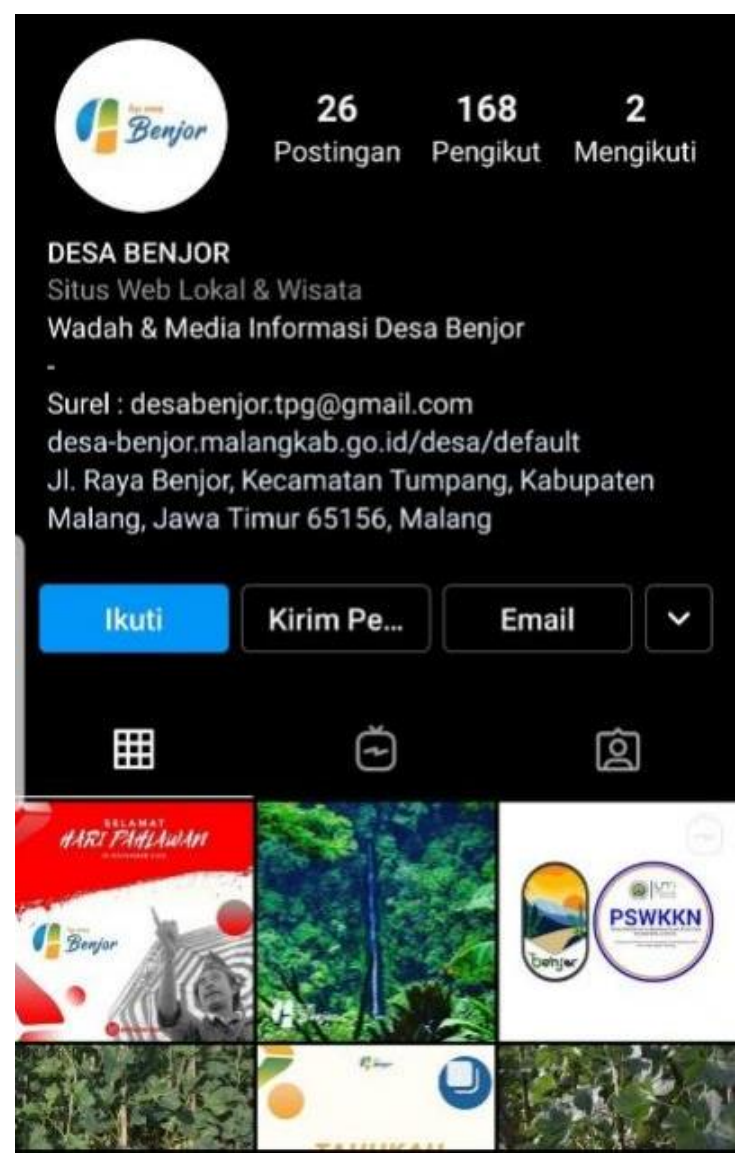

Fig. 2. Dashboard Instagram Benjor Village

Benjor Village tourism promotion Instagram is addressed to http://instagram.com/desabenjor?igshid=1wvzqx3z7bFqu or @ desabenjor. Meanwhile, the address for access to the promotion of Benjor Village is http://desa-benjor.malangkab.go.id/desa/default. 


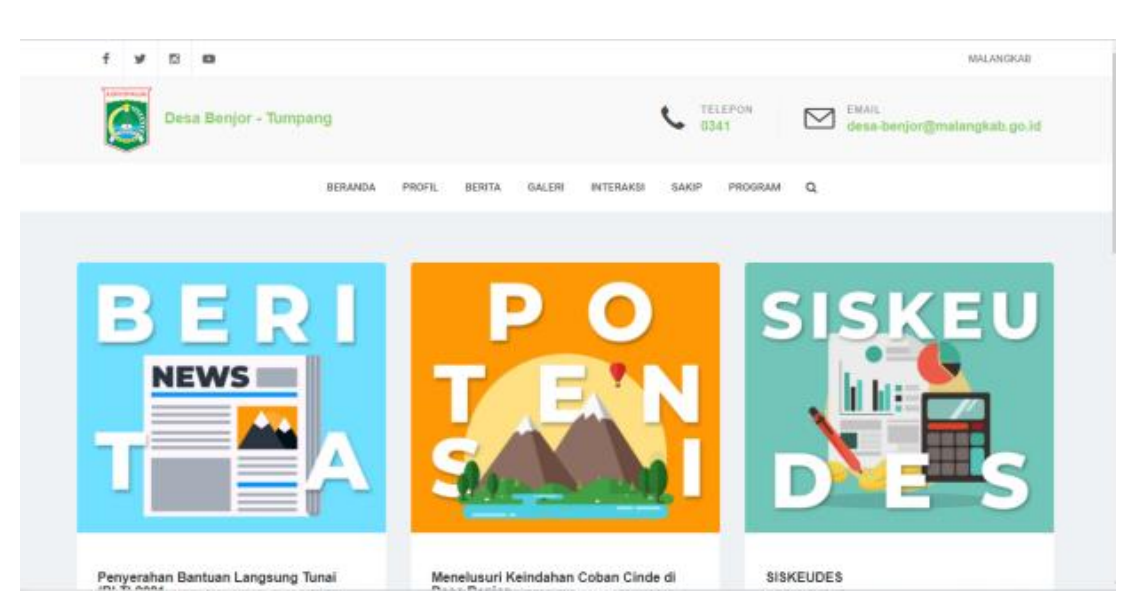

Fig. 3.Dashboard Website Benjor Village

The website and Instagram, which residents in the first ten days entirely operated, were visited by 150 users outside the village of Benjor. This number will continue to grow as long as the account is operated according to the provision. The final product, which has been entirely operated by the residents and village officials of Benjor, is only a prototype of branding for an independent tourism village. The village government, district government, and the tourism office are necessary for the sustainability of the realization of the Benjor tourist village. Through action research and development involving residents and village officials, Benjor village is now known to the people of Malang and its surroundings as a village with environmental, artistic and culinary potential as tourism assets. Tourism assets can improve the economy of the Benjor village community through promotional products. The actual promotional products needed by Benjor village are (1) logo, (2) song, (3) dance, (4) tagline, (5) bumper video, (6) Instagram, and (7) website. The seven promotional products produced as one of the outputs of this research are expected to be followed up by the community, village officials, village governments, and the academic community in the agenda of accelerating Benjor Village to become a tourism village in Malang Regency.

\section{Conclusion}

This paper focuses on the tourism of Banjor village branding by using hybrid action research and development research. The finding shows that the best approach or strategy to improve the branding of Benjor Village as a tourist village is synergizing art, nature, and culinary arts in logos, songs, dances, taglines, videos, and social media. To sum up, Benjor village branding through this production contributes to creating allure and finding effective strategies for village branding at the foot of the mountain.

\section{References}

Aryanti, Tutin. 2015. "Branding the Islamic Village: Modesty and Identity in Yogyakarta Kauman Village, Indonesia." Procedia - Social and Behavioral Sciences 184 (May): 126-34. https://doi.org/10.1016/j.sbspro.2015.05.070.

Azizah, Siti, U Wisaptiningsih, A E Kusumastuti, and J A Putritamara. 2020. "Goat Farming Development Strategy in Benjor Village, Malang Regency, Indonesia.” Technium Soc. Sci. J. 5: 217.

Bonnardel, Valérie, Hugues Séraphin, Vanessa Gowreesunkar, and Michele Ambaye. 2020. "Empirical Evaluation of the New Haiti DMO Logo: Visual Aesthetics, Identity and Communication Implications." Journal of Destination Marketing \& Management 15 (March): 100393. https://doi.org/10.1016/j.jdmm.2019.100393.

Burgess, Jean. 2015. "From 'Broadcast Yourself'to 'Follow Your Interests': Making over Social Media." International Journal of Cultural Studies 18 (3): 281-85.

Casidy, Riza, Walter Wymer, and Aron O'Cass. 2018. "Enhancing Hotel Brand Performance through Fostering Brand Relationship Orientation in the Minds of Consumers." Tourism Management 66 (June): 72-84. https://doi.org/10.1016/j.tourman.2017.11.008. 
Chakraborty, Shamik, Shantanu Kumar Saha, and Samiya Ahmed Selim. 2020. "Recreational Services in Tourism Dominated Coastal Ecosystems: Bringing the Non-Economic Values into Focus." Journal of Outdoor Recreation and Tourism 30: 100279.

Damiasih, D., and Isdarmanto. 2020. "The Role of Multimedia in Developing Ecotourism Branding of Yogyakarta Special Region (DIY).” Tourism Research Journal 1 (1).

Jiang, Yanfeng, Hualou Long, Yu-ting Tang, Wu Deng, Kunqiu Chen, and Yuhan Zheng. 2021. "The Impact of Land Consolidation on Rural Vitalization at Village Level: A Case Study of a Chinese Village." Journal of Rural Studies 86 (August): 485-96. https://doi.org/10.1016/j.jrurstud.2021.07.004.

Kastenholz, Elisabeth, Celeste Eusébio, and Maria João Carneiro. 2018. "Segmenting the Rural Tourist Market by Sustainable Travel Behaviour: Insights from Village Visitors in Portugal." Journal of Destination Marketing \& Management 10 (December): 132-42. https://doi.org/10.1016/j.jdmm.2018.09.001.

Khairabadi, Omid, Hassan Sajadzadeh, and Saheb Mohammadianmansoor. 2020. "Assessment and Evaluation of Tourism Activities with Emphasis on Agritourism: The Case of Simin Region in Hamedan City." Land Use Policy 99 (December): 105045. https://doi.org/10.1016/j.landusepol.2020.105045.

Kladou, Stella, Mihalis Kavaratzis, Irini Rigopoulou, and Eleftheria Salonika. 2017. "The Role of Brand Elements in Destination Branding." Journal of Destination Marketing \& Management 6 (4): 426-35.

Kong, Hyun Min, Alexander Witmaier, and Eunju Ko. 2021. "Sustainability and Social Media Communication: How Consumers Respond to Marketing Efforts of Luxury and Non-Luxury Fashion Brands.” Journal of Business Research 131 (July): 640-51. https://doi.org/10.1016/j.jbusres.2020.08.021.

Lichtenfeld, Stephanie, Andrew J Elliot, Markus A Maier, and Reinhard Pekrun. 2012. "Fertile Green: Green Facilitates Creative Performance.” Personality and Social Psychology Bulletin 38 (6): 784-97.

Madleňáková, Lucia, Stanislava Turská, and Radovan Madleňák. 2019. “The Image of the Postal Company as a Key Attribute of the Customer's Purchasing Behaviour.” Transportation Research Procedia 40: 108895. https://doi.org/10.1016/j.trpro.2019.07.152.

Marshall, Shantal R., and Laura P. Naumann. 2018. "What's Your Favorite Music? Music Preferences Cue Racial Identity." Journal of Research in Personality 76 (October): 74-91. https://doi.org/10.1016/j.jrp.2018.07.008.

Mayer, Richard E, and Roxana Moreno. 2002. "Animation as an Aid to Multimedia Learning." Educational Psychology Review 14 (1): 87-99.

Miclon, Valentin, Samuel Bédécarrats, Boris Laure, Elisabeth Zadora-Rio, Matthieu Gaultier, Hélène Coqueugniot, and Estelle Herrscher. 2021. "Disability in a Medieval Village Community: A Unique Case of Facial Dysmorphism." International Journal of Paleopathology 35 (December): 22-28. https://doi.org/10.1016/j.ijpp.2021.08.002.

Padurean, Loredana. 2007. "Marketing Higher Education Based on Location Attributes."

Park, Hayun, and Jason F. Kovacs. 2020. "Arts-Led Revitalization, Overtourism and Community Responses: Ihwa Mural Village, Seoul." Tourism Management Perspectives 36 (October): 100729. https://doi.org/10.1016/j.tmp.2020.100729.

Porter, Michael E. 1989. "How Competitive Forces Shape Strategy." In Readings in Strategic Management, 133-43. Springer.

Sajnani, Nisha, Christine Mayor, and Heather Tillberg-Webb. 2020. “Aesthetic Presence: The Role of the Arts in the Education of Creative Arts Therapists in the Classroom and Online.” The Arts in Psychotherapy 69 (July): 101668. https://doi.org/10.1016/j.aip.2020.101668.

Tasci, Asli D. A., and Metin Kozak. 2006. "Destination Brands vs Destination Images: Do We Know What We Mean?” Journal of Vacation Marketing 12 (4): 299-317. https://doi.org/10.1177/1356766706067603.

Wang, Luyu, and Andrei P Kirilenko. 2021. "Do Tourists from Different Countries Interpret Travel Experience with the Same Feeling? Sentiment Analysis of TripAdvisor Reviews." In Information and Communication Technologies in Tourism 2021, 294-301. Springer. 
Wang, Nian, Ming Fang, Michelle Beauchamp, Ziyu Jia, and Zhengxu Zhou. 2021. “An Indigenous Knowledge-Based Sustainable Landscape for Mountain Villages: The Jiabang Rice Terraces of Guizhou, China." Habitat International 111 (May): 102360. https://doi.org/10.1016/j.habitatint.2021.102360.

Yampolsky, Philip. 2018. "Javanese Gamelan and the West by Sumarsam." Asian Music 49 (2): 158-62. https://doi.org/10.1353/amu.2018.0019.

Zhou, Lingxu, Geoffrey Wall, Dapeng Zhang, and Xiaoyun Cheng. 2021. "Tourism and the (Re)Making of Rural Places: The Cases of Two Chinese Villages.” Tourism Management Perspectives 40 (October): 100910. https://doi.org/10.1016/j.tmp.2021.100910. 